Print ISSN: 2502-1397 / Online ISSN 2540-8100

https://doi.org/10.32505/j-ebis.v6i1.2624

\title{
KELAYAKAN DAN KEADILAN DALAM PENETAPAN UPAH NELAYAN KAPAL PUKAT LANGGAR KUALA LANGSA DITINJAU DARI PERSPEKTIF ETIKA BISNIS ISLAM
}

\author{
Nurmala Sari*, Safwan Kamal**, Junaidi***, Mastura**** \\ *Institut Agama Islam Negeri Langsa, sari7892@gmail.com \\ **Institut Agama Islam Negeri Langsa, safwankamal@iainlangsa.ac.id \\ ***Institut Agama Islam Negeri Langsa, junaidi.erda@gmail.com \\ *****nstitut Agama Islam Negeri Langsa, mastura@iainlangsa.ac.id
}

\begin{abstract}
Wages are a form of income as a reward given by the owner of the boat to fishermen for services that have been provided. Wages serve as a guarantee for the survival of fishermen so that boat owners must provide wages in accordance with their work and fishermen must work according to the agreement. The problem occurs if there is no written work agreement regarding the determination of wages, so that if the policy in work activities is fully controlled by the handler, the handler may act fraudulently in setting wages and also in taking an action such as unilaterally terminating the job without the ship owner's knowledge. The purpose of this study is to determine the feasibility and fairness in determining the wages of fishing trawlers in Kuala Langsa and to find out the views in Islamic Business Ethics. This type of research is a field study (field research) with descriptive qualitative research methods. Primary data were obtained from interviews with boat owners and fishermen in 5 trawler businesses in Kuala Langsa, while secondary data were obtained through books, scientific papers and documents used to answer problems in research. The researcher concludes that the determination of wages for fishing trawlers in Kuala Langsa is not against Islamic Business Ethics because there is willingness from each party and the fish income obtained is also calculated in a transparent manner. In this case, the fishermen don't feel wronged because each party receives a legal wage according to the level of their work without being wrongful to the other and the rights and obligations of each party (boat owners and fishermans) have been fulfilled.
\end{abstract}

Keyword: Islamic business ethics, appropriateness, justice and wage fixing.

\begin{abstract}
Abstrak
Pengupahan merupakan suatu bentuk penerimaan sebagai imbalan yang diberikan oleh pemilik kapal kepada nelayan atas jasa yang telah diberikan. Upah berfungsi sebagai jaminan kelangsungan hidup bagi nelayan sehingga pemilik kapal harus memberikan upah sesuai dengan pekerjaan dan nelayan harus bekerja sesuai dengan perjanjian. Permasalahan terjadi jika tidak ada perjanjian kerja tertulis mengenai penetapan upah, sehingga apabila kebijakan dalam kegiatan kerja sepenuhnya di pegang oleh pawang, maka pawang bisa saja berlaku curang dalam penetapan upah dan juga dalam mengambil suatu tindakan seperti pemutusan
\end{abstract}


kerja secara sepihak tanpa sepengetahuan pemilik kapal. Tujuan dalam penelitian ini adalah untuk mengetahui kelayakan dan keadilan dalam penetapan upah nelayan kapal pukat langgar di Kuala Langsa dan untuk mengetahui pandangan dalam Etika Bisnis Islam. Jenis penelitian yang digunakan adalah studi lapangan (field research) dengan metode penelitian kualitatif deskripstif. Data primer diperoleh dari hasil wawancara dengan pemilik kapal dan nelayan pada 5 usaha kapal pukat langgar di Kuala Langsa, sedangkan data sekunder diperoleh melalui buku, karya ilmiah dan dokumen-dokumen yang digunakan untuk menjawab masalah dalam penelitian. Peneliti menyimpulkan bahwa dalam penetapan upah nelayan kapal pukat langgar di Kuala Langsa tidak bertentangan dengan Etika Bisnis Islam karena terjadi kerelaan dari masing-masing pihak serta penghasilan ikan yang didapatkan juga dihitung secara transparansi. Dalam hal ini, para nelayan tidak ada yang merasa teraniaya karena masing-masing pihak memperoleh besaran upah yang sah sesuai dengan tingkatan pekerjaannya tanpa bersikap dzalim terhadap yang lainnya dan sudah terpenuhinya hak dan kewajiban dari masing-masing pihak (pemilik kapal dan nelayan).

Kata Kunci: Etika Bisnis Islam, Kelayakan, Keadilan dan Penetapan Upah.

\section{PENDAHULUAN}

Nelayan merupakan bagian dari masyarakat yang hidup dipedesaan pesisir dan memiliki kekhasan tersendiri yang berbeda dengan kondisi masyarakat di luar komunitasnya, baik dari sudut pandang geoekologi, ekonomi maupun sosial. Secara ekologi dan geografis masyarakat pesisir diuntungkan dengan luasnya lahan garapan mereka. Namun secara ekonomi masyarakat pesisir dihadapkan dengan ketidakpastian. Pendapatan nelayan umumnya rendah, sedangkan modal atau biaya yang dikeluarkan cukup besar. Selain itu, masyarakat pesisir dihadapkan langsung dengan ekosistem yang keras, dan sumber daya kehidupan yang bergantung kepada pemanfaatan sumber daya pesisir dan laut (Lina Asmara Wati, 2018). Oleh karena itu, peran pemilik kapal atau disebut toke menjadi sangat penting bagi masyarakat yang berprofesi nelayan karena untuk mereka yang tidak memiliki modal dapat bekerja sama dengan pemilik kapal yang hanya bermodalkan skill dan pengalamannya dalam mencari ikan di laut.

Desa Kuala Langsa memiliki banyak kapal pukat langgar yang beroperasi di pelabuhan Kuala Langsa yang disebut dengan Pelabuhan TPI Kuala Langsa. Disini penulis ingin melakukan penelitian pada 5 kapal pukat langgar yang terdiri dari kapal "KM Mentari” dengan pemilik kapal yang bernama Haji Amir, kemudian Bapak Putra sebagai pemilik kapal "Rezeqi Rabbi", kapal "Hikmah Laut” yang dimiliki oleh Bapak Karya, kapal "KM Putra Lingga” dengan pemilik 
kapal bernama Bapak Ridwan dan yang terakhir kapal "Putra Jaya" dengan pemilik kapal yang bernama Bapak Jamal. Masing-masing kapal pukat langgar tersebut sudah berjalan lebih dari 1 tahun. Namun para nelayan kapal pukat langgar sering mengeluh tentang upah yang diberikan oleh pemilik kapal. Berdasarkan observasi awal, pemilik kapal sering melakukan keterlambatan dalam memberikan upah kepada pekerjanya yaitu nelayan. Pekerja atau nelayan yang telah menjalankan pekerjaan atau kewajibannya harus pulang dengan tangan kosong karena upah mereka tidak segera diberikan oleh pemilik kapal tersebut. Padahal sebelum kapal berangkat, sudah ada perjanjian awal antara pemilik kapal dengan pekerja-pekerja tentang pemberian upah mereka (Yahya, 2019). Hal tersebut merupakan pelanggaran Peraturan Pemerintah Republik Indonesia Nomor 78 Tahun 2015 tentang pengupahan yang tercantum dalam Pasal 5 ayat (4) huruf (a) yang berbunyi: "mulai dari hari keempat sampai dengan hari kedelapan terhitung tanggal seharusnya upah di bayar, dikenakan denda sebesar 5\% (lima persen) untuk setiap hari keterlambatan dari upah yang seharusnya dibayarkan”.

Bagi seseorang yang berprofesi nelayan, bekerja sama dengan pengusahaa itu sangat dibutuhkan karena tidak semua nelayan memiliki modal untuk membuat kapal sendiri, membuat kapal pukat langgar itu membutuhkan modal hingga puluhan juta sehingga para nelayan tidak mampu untuk membuatnya. Oleh sebab itu, para nelayan harus lebih rajin dan giat dalam mengandalkan kemampuannya agar tidak kehilangan pekerjaan dan hasil pekerjaan yang dilakukan juga disukai oleh pemilik kapal tersebut. Namun dari beberapa pengusaha yang ada di Desa Kuala Langsa ini sering kali mengalami kesilapan dalam memberikan upah nelayan yang bekerja padanya, dimana antara para nelayan yang malas dan nelayan yang rajin mendapatkan bagian upah yang sama atau tidak sesuai. Hal ini menyebabkan perselisihan diantara para nelayan tersebut karena pekerjaan yang seharusnya tidak menjadi beban pekerjaan namun harus dikerjakan, tetapi tidak mendapatkan imbalan atas pekerjannya. Dalam hal ini terjadi ketidakadilan dalam pembagian upah para pekerja khususnya mereka yang menjalankan pekerjaan lebih tersebut (Rusmadi, 2020).

Pada dasarnya dalam Islam, pekerja memiliki hak yaitu hak untuk bekerja, hak untuk memperoleh gaji/upah, hak cuti dan keringanan pekerjaan serta hak memperoleh jaminan dan perlindungan. Jika membahas hak dalam memperoleh 
gaji/upah maka kaidah Islam menegaskan bahwa gaji/upah harus sesuai dengan pekerjaan.

Etika Bisnis Islam memiliki prinsip dasar, yaitu berasaskan kelayakan dan keadilan yang diwujudkan dari seseorang yang menjunjung tinggi nilai kebenaran, kejujuran dan keberanian untuk mengambil keputusan baik serta terhindar dari berbuat zalim. Hal ini menjelaskan bahwa dalam penetapan upah juga harus menerapkan kejujuran dan kebenaran agar terjalinnya hubungan kerja sama yang baik antara pengusaha dengan pekerjanya (Bustanul Karim, 2018).

Kelayakan dapat dilihat dari tingkat kesejahteraan seorang pekerja dan laba usaha yang didapatkan pekerja maupun pengusaha, sedangkan keadilan dapat dilihat dari keseimbangan antara pengorbanan yang dilakukan dengan penghasilan yang didapatkan pekerja maupun pengusaha tersebut. Sehingga dalam menetapkan upah seorang pekerja harus memenuhi prinsip kelayakan serta keadilan, agar seorang pengusaha tersebut dapat dikatakan sebagai pengusaha yang memiliki etika bisnis yang sesuai syariat Islam.

Dari pernyataan latar belakang permasalahan di atas, penulis tertarik untuk melakukan penelitian terkait penetapan upah yang dilakukan oleh pengusaha kapal pukat langgar, sehingga tersusun judul yang akan diteliti yaitu: "Kelayakan Dan Keadilan Dalam Penetapan Upah Nelayan Kapal Pukat Langgar Kuala Langsa Ditinjau Dari Perspektif Etika Bisnis Islam”

\section{LANDASAN TEORITIS}

\section{Kelayakan}

Kelayakan dapat diartikan sebagai usaha yang dijalankan akan memberikan keuntungan financial atau nonfinansial sesuai dengan tujuan yang mereka inginkan. Keuntungan tersebut tidak hanya untuk pengusaha yang menjalankannya tetapi juga untuk debitur, pemerintah bahkan masyarakat luas (Kasmir, 2013). Oleh karena itu, dalam penetapan upah pekerja atau nelayan harus diukur dengan tingkat kelayakannya. Dimana kelayakan tersebut dapat dilihat dari kemampuan pekerja atau nelayan dalam memenuhi kebutuhan keluarganya.

\section{Keadilan}

Keadilan artinya keutamaan yang sempurna dan tidak bersifat pribadi, karena berkaitan dengan orang banyak. Karenannya, keadilan merupakan nilai keutamaan 
yang paling penting. Terbit dan tenggelamnya matahari pun tak dapat mengalahkan pentingnnya keadilan. Jadi keadilan dianggap sebagai keutamaan sempurna karena orang yang adil adalah orang yang dapat merealisasikan terwujudnya keadilan, tidak hanya kepada dirinya sendiri tapi juga kepada orang lain. Hal ini menjelaskan bahwa keadilan juga berpengaruh dengan kesejahteraan orang lain, begitu juga dengan kesejahteraan seorang pekerja atau nelayan dapat dilihat pada saat pemberian upah yang berlaku adil.

\section{Penetapan Upah}

Berbagai teori dikemukakan oleh para ahli ekonomi modern mengenai penentuan atau penetapan upah diantaranya yaitu, menurut subsistence theory, upah cenderung mengarah ke suatu tingkat yang hanya cukup untuk memenuhi kebutuhan minimum pekerja dan keluarganya (Sharif Chaudhry, 2013). Oleh karena itu, bagi seorang pekerja atau nelayan penetapan upah itu sangat penting dikarenakan upah yang ditetapkan menentukan besar kecilnya kemampuan seseorang dalam memenuhi konsumsi keluarganya.

\section{Nelayan}

Menurut Peraturan Pemerintah Republik Indonesia Nomor 78 Tahun 2015 tentang Pengupahan menyebutkan bahwa pekerja/buruh adalah setiap orang yang bekerja dengan menerima upah atau imbalan dalam bentuk lain. Pengertian pekerja dalam penelitian ini adalah orang yang berkewajiban bekerja kepada pemilik usaha pada kapal pukat langgar dimana pekerjaan tersebut berasal dari bidang perikanan dengan mengharapkan pendapatan dari laut.

\section{Etika Bisnis Islam}

Etika bisnis dalam Islam adalah sejumlah perilaku etis bisnis (akhlaq al Islamiyah) yang dibungkus dengan nilai-nilai syari'ah yang mengedepankan halal dan haram. Jadi perilaku yang etis itu ialah perilaku yang mengikuti perintah Allah dan menjauhi larangan-Nya (Fitri Amalia, 2014). Sedangkan menurut Djakfar, etika bisnis Islam adalah norma-norma etika yang berbasiskan Al-qur'an dan Hadits yang harus dijadikan acuan oleh siapapun dalam aktivitas bisnis (Djakfar, 2012). Oleh karena itu, pengusaha kapal pukat langgar juga harus memiliki etika dalam menjalankan bisnis, sebagai pengusaha muslim haruslah menjalankan bisnis dengan meraih kemaslahatan dunia dan akhirat. Jadi bisnis yang dijalankan haruslah sesuai dengan syariat Islam. 


\section{METODE}

Penelitian ini menggunakan jenis penelitian studi lapangan (field research). Field research yang dilakukan dalam penelitian ini menghasilkan data yang diartikan sebagai data yang fakta atau informasi dari pelaku (subjek penelitian), aktivitas, dan tempat yang menjadi subjek penelitiannya. Dalam penelitian ini, yang menjadi subjek penelitian adalah pemilik kapal pukat langgar, dan nelayan.

Penelitian ini juga menggunakan metode penelitian kualitatif yaitu jenis penelitian yang dilakukan pada kondisi objek penelitian yang alami sesuai dengan keadaan yang nyata dan teknik pengumpulan data dilakukan secara gabungan, dapat juga disebut dengan deskriptif. Deskriptif merupakan uraian sistematis tentang teori (bukan sekedar pendapat pakar atau penulis buku) dan hasil-hasil penelitian yang relevan dengan cara mendeskripsikan atau menggambarkan data yang telah terkumpul dari suatu fenomena yang terjadi (Sugiono, 2010). Oleh karena itu, penulis ingin mendeskripsikan sistem penetapan upah nelayan yang ada di Kuala Langsa apakah sudah sesuai dengan prinsip kelayakan dan keadilan dalam Etika Bisnis Islam.

Sumber data yang dimaksud dalam penelitian ini adalah subjek dari mana data dapat diperoleh. Dalam penelitian ini peneliti hanya akan meneliti sebagian dari populasi untuk dijadikan sampel. Menurut Sugiyono (2010), populasi merupakan wilayah generalisasi atau keseluruhan subyek penelitian yang mempunyai kualitas dan karakteristik tertentu yang ditetapkan oleh peneliti, sedangkan sampel adalah sebagian dari jumlah dan karakteristik yang dimiliki oleh populasi tersebut. Maka populasi dari penelitian ini adalah seluruh penduduk yang ada di Desa Kuala Langsa yang berprofesi sebagai nelayan yang berjumlah 958 orang, sedangkan sampel yang diambil berdasarkan sampel yang telah ditentukan (purposive sampling) yaitu nelayan yang bekerja pada kapal pukat langgar yang sudah bergerak lebih kurang 1 tahun dimana masing-masing kapal memiliki jumlah pekerja sekitar 35-40 orang pekerja. Purposive sampling digunakan untuk pengambilan subjek penelitian untuk tujuan tertentu dengan syarat-syarat yang telah ditentukan oleh peneliti, bukan berdasarkan strata atau random. Jadi dalam penelitian ini, penulis mencari informan yang tepat dan sesuai dengan kebutuhan untuk menjadi narasumber penelitian. Adapun sumber data dalam penelitian 
initerdiri dari yang pertama data primer, peneliti mendapatkan data dari informan langung yaitu pemilik dan nelayan yang bekerja di kapal pukat langgar yang berlokasi di Kuala Langsa. Yang kedua data Sekunder, Data-data sekunder tersebut, diantaranya diperoleh dari Kepala Desa mengenai jumlah penduduk yang berprofesi sebagai nelayan, berapa usia penduduk yang berprofesi nelayan dan tingkat pendapatan nelayan tersebut. Selain dari itu, data yang diperoleh dapat melalui karya ilmiah dan berita-berita yang digunakan untuk menjawab masalah dalam penelitian.

Metode pengumpulan data yang akan dilakukan dalam penelitian ini menggunakan teknik wawancara, observasi dan dokumentasi.

Teknik analisis data, dimana pada dasarnya analisis data merupakan penguraian data melalui tahapan kategorisasi dan klasifikasi, perbandingan dan pencarian penjelasan. Analisis data dalam penelitian ini adalah data yang muncul berupa kata-kata dan bukan merupakan rangkaian angka seta prosedur analisis data terbagi tiga, yaitu: Pengurangan data (reduksi),Penyajian data (display) dan Penarikan kesimpulan (conclusion).

\section{HASIL DAN PEMBAHASAN}

\section{Sistem Penetapan Upah Pada Kapal Pukat Langgar}

Upah adalah suatu penerimaan sebagai imbalan yang diberikan oleh pemberi kerja kepada penerima kerja atas jasa yang telah dilakukan. Upah berfungsi sebagai jaminan kelangsungan hidup yang layak bagi pekerja. Sehingga apabila sistem penetapan upah dilakukan dengan baik akan memberikan kesejahteraan bagi pekerjanya. Dan hal ini akan berdampak bagi kemajuan suatu usaha, dimana jika pekerja merasa puas dengan ketetapan yang ditetapkan oleh pengusaha, maka pekerja akan menjalakan tugasnya dengan hasil yang maksimal. Tetapi jika sebaliknya, maka akan membuat kemerosotan suatu usaha dalam hal produksi karena pekerja tidak menjalakan dengan maksimal.

Sistem penetapan upah pada kapal pukat langgar di Kuala Langsa disesuaikan dengan banyaknya hasil tangkapan ikan yang didapatkan oleh pekerja di suatu kapal. Sehingga apabila tangkapan ikan yang dihasilkan banyak, maka upah yang diterima oleh pekerja juga banyak. Hal tersebut dapat menjadi apresiasi pekerja untuk bekerja lebih maksimal. Namun hasil tangkapan ikan tersebut tidak 
Nurmala Sari, dkk: Kelayakan dan Keadilan dalam Penetapan Upah

dapat diprediksikan karena hasil tangkapan ikan berpengaruh dengan kondisi alam seperti angin ribut atau badai laut yang akan berdampak sedikitnya hasil tangkapan ikan dan berpengaruh juga dengan keselamatan pekerja. Sehingga setiap pekerja kapal pukat langgar yang ada di Kuala Langgar diberikan jaminan kesehatan secara langsung oleh pemilik kapal.

Sistem upah pada umumnya di pandang sebagai suatu perangkat mekanisme untuk menyalurkan upah kepada karyawan. Ada beberapa sistem yang digunakan untuk menyalurkan upah. Dimana masing-masing sistem tersebut akan mempunyai pengaruh yang spesifik terhadap dorongan dan semangat kerja serta nilai-nilai yang akan di capai. Ada beberapa cara atau sistem yang digunakan untuk memperhitungkan besarnya upah yang sering digunakan adalah sebagai berikut:

1. Upah menurut prestasi yaitu besarnya balas karya langsung dikaitkan dengan prestasi kerja, karena besarnya upah tergantung dari banyak sedikitnya hasil yang dicapai dalam waktu tertentu.

2. Upah waktu yaitu sistem upah berdasarkan lamanya waktu pekerja melakukan pekerjaan bagi pemilik usaha, bisa dihitung perjam, perhari, perminggu atau perbulan.

3. Upah borongan yaitu balas jasa yang dibayar untuk suatu pekerjaan yang diborongkan. Cara memperhitungkan upah itu kerap kali dipakai pada suatu pekerjaan yang diselesaikan oleh suatu kelompok pekerja. Untuk seluruh pekerjaan ditentukan suatu balas jasa yang kemudian dibagi-bagi antara para pelaksana.

4. Upah premi merupakan kombinasi antara upah waktu dan upah potongan. Upah dasar untuk prestasi normal berdasarkan waktu atau jumlah hasil. Apabila seorang pekerja mencapai prestasi yang lebih dari itu, ia di beri premi.

5. Upah bagi hasil yaitu sistem yang banyak dipakai dibidang pertanian dan dalam usaha keluarga, namun juga dikenal diluar kalangan itu, yang mana karyawan ikut menerima bagian dari keuntungan bersih perusahaan.

Sementara itu, sistem yang diterapkan oleh kapal pukat langgar di Kuala Langsa adalah sistem upah bagi hasil. Berdasarkan hasil wawancara dengan Bapak Ridwan sebagai pemilik kapal yang menyatakan bahwa: 
“Total pendapatan upah nelayan itu dilihat dari hasil tangkapan ikan yang mereka dapatkan secara keseluruhan yang kemudian dijual dengan harga pasar. Kemudian dilakukan bagi hasil kepada toke dengan persentase 70:30 artinya keseluruhan penjualan ikan tersebut diberi 70\% untuk toke dan 30\% diberikan kepada pawang lalu pawang akan membagikan upah-upah nelayan tersebut dan dari $30 \%$ itu memang selalu disalurkan ke masjid $1 \%$ nya".

Berdasarkan pernyataan di atas menjelaskan bahwa sistem yang digunakan adalah sistem bagi hasil antara pemilik modal dengan pengelola. Dimana yang menjadi pengelola disini adalah pawang dan anggota kerjanya. Dari pernyataan tersebut juga dapat disimpulkan bahwa penghasilan dari kapal pukat langgar di Kuala Langsa merupakan pendapatan bersih hasil penjualan ikan karena beban operasional kapal sebelum melaut sudah di tanggung oleh pemilik modal yaitu toke atau pemilik kapal pukat langgar.

Adapun beberapa macam sistem penetapan upah dalam teori maupun praktik adalah sebagai berikut:

1. Sistem Upah Jangka Waktu adalah sistem pemberian upah menurut jangka waktu tertentu, misalnya harian, mingguan atau bulanan.

2. Sistem Upah Potongan, Sistem ini umumnya bertujuan untuk mengganti sistem upah jangka waktu jika hasilnya tidak memuaskan. Sistem upah ini hanya dapat diberikan jika hasil pekerjaannya dapat dinilai menurut ukuran tertentu, misalnya diukur dari banyaknya, beratnya dan sebaginya.

3. Sistem Upah Permufakatan adalah suatu sistem pemberian upah dengan cara memberikan sejumlah upah pada kelompok tertentu. Selanjutnya, kelompok ini akan membagi-bagikan kepada para anggotanya.

4. Sistem Skala Upah Berubah, dalam sistem ini jumlah upah yang diberikan berkaitan dengan penjualan hasil produksi di pasar. Jika harga naik jumlah upahnya akan naik. Sebaliknya, jika harga turun, upah pun akan turun. Itulah sebabnya disebut skala upah berubah.

5. Sistem Upah Indeks, sistem upah ini di dasarkan atas indeks biaya kebutuhan hidup. Dengan sistem ini upah akan naik turun sesuai dengan naik turunnya biaya penghidupan meskipun tidak mempengaruhi nilai nyata dari upah.

6. Sistem Pembagian Keuntungan, Sistem upah ini dapat disamakan dengan pemberian bonus apabila perusahaan mendapat keuntungan di akhir tahun. 
7. Sistem upah borongan adalah balas jasa yang dibayar untuk suatu pekerjaan yang diborongkan. Cara memperhitungkan upah ini kerap kali dipakai pada suatu pekerjaan yang diselesaikan oleh suatu kelompok pekerja, untuk seluruh pekerjaan ditentukan suatu balas karya yang kemudian di bagi-bagi antara pelaksana.

8. Sistem upah premi, cara pemberian upah ini merupakan kombinasi dari upah waktu dan upah potongan. Upah dasar untuk prestasi normal berdasarkan waktu atau jumlah hasil apabila semua karyawan mencapai prestasi yang lebih dari itu. Diberikan penghemat waktu, penghemat bahan, kualitas produk yang baik dan sebagainya.

Sementara itu, sistem yang digunakan dalam menetapkan upah para nelayan yaitu dengan sistem skala upah berubah. Berdasarkan dari hasil wawancara dengan Syafrizal sebagai nelayan menyatakan:

"Upah yang kami dapatkan itu tidak tetap, jadi kalau misalkan pendapatan banyak terus harga ikan di pasar pun mahal, kami bisa dapat upah yang banyak. Tapi kalau harga ikan di pasaran murah, mau kami dapat ikan banyak pun jadi upah kami sedikit karena ikan murah. Terus untuk pembagian upah kami pun disesuaikan dengan pekerjaan yang kami kerjakan. Bagiannya itu ada tingkatannya, misalkan kayak saya bidang pekerjaan pawang yang mendapatkan 4 bagian (4 kali lipat) dengan upah pokok paling sedikit yaitu Rp. 50.000,- maka di kali 4 bagian menjadi Rp. 200.000,- dan di tambah upah pokok sehingga menjadi Rp. 250.000,- untuk upah pekerja di bidang pawang. Begitu juga dengan bidang lainnya seperti masinis yang mendapat bagian 3 kali lipat, sedangkan untuk nakhoda mendapat 2 kali lipat dan untuk ABK lainnya mendapat 1 bagian atau 1 kali lipat. Jadi sesuai tingkat kesulitan kerjanya juga gitu”.

Berdasarkan pernyataan di atas menjelaskan bahwa upah yang akan dibagikan kepada para nelayan tersebut disesuaikan dengan hasil penjualan ikan yang berarti para nelayan akan mendapatkan upah yang banyak apabila banyaknya hasil tangkapan ikan di dukung dengan naiknya harga ikan di pasar. Sedangkan untuk besaran upahnya disesuaikan dengan tingkat kesulitan dari bidang pekerjaan masing-masing. Adapun kalkulasi upah nelayan berdasarkan tingkatan pekerjaan sebagai berikut: 
Tabel 1.1.

Kalkulasi Pembagian Upah

\begin{tabular}{|c|c|c|c|}
\hline \multirow{2}{*}{$\mathrm{NO}$} & \multicolumn{3}{|c|}{$\begin{array}{l}\text { Misalkan: pendapatan } 30 \% \text { pembagian untuk pengelola masing-masing } \\
\text { mendapatkan upah pokok Rp.50.000,- }\end{array}$} \\
\hline & $\begin{array}{c}\text { Bidang } \\
\text { Pekerjaan }\end{array}$ & $\begin{array}{l}\text { Tingkat } \\
\text { Bagian }\end{array}$ & Hasil \\
\hline 1 & Pawang & 4 Bagian & $\begin{array}{l}\text { Rp.50.000,- dikali } 4 \text { bagian menjadi Rp. } 200.000,- \\
\text { ditambah upah pokok menjadi Rp.250.000,- }\end{array}$ \\
\hline 2 & Masinis & 3 Bagian & $\begin{array}{l}\text { Rp.50.000,- dikali } 3 \text { bagian menjadi Rp. 150.000,- } \\
\text { ditambah upah pokok menjadi Rp.200.000,- }\end{array}$ \\
\hline 3 & $\begin{array}{l}\text { Nakhoda } \\
\text { Juru } \\
\text { Lampung } \\
\text { Juru Batu } \\
\text { Juru } \\
\text { Sampan }\end{array}$ & 2 Bagian & $\begin{array}{l}\text { Rp.50.000,- dikali } 2 \text { bagian menjadi Rp. 100.000,- } \\
\text { ditambah upah pokok menjadi Rp.150.000,- }\end{array}$ \\
\hline 4 & $\begin{array}{l}\text { Anak Buah } \\
\text { Kapal } \\
\text { (ABK) } \\
\text { Penjaga } \\
\text { Kapal }\end{array}$ & 1 Bagian & $\begin{array}{l}\text { Rp.50.000,- ditambah upah pokok menjadi Rp. } \\
\text { 100.000,- }\end{array}$ \\
\hline
\end{tabular}

Dari hasil pemaparan diatas dapat simpulkan bahwa sistem yang diterapkan kapal pukat langgar di Kuala Langsa, adalah sebagai berikut:

Tabel 1.2.

Sistem Penetapan Upah Pada Kapal Pukat Langgar

\begin{tabular}{|c|l|l|}
\hline NO. & \multicolumn{2}{|c|}{ Sistem Penetapan Upah Pada Kapal Pukat Langgar } \\
\hline 1 & Upah Bagi Hasil & $\begin{array}{l}\text { Pendapatan sesuai persentase bagi hasil antara pemilik kapal } \\
\text { dengan pekerja (nelayan). }\end{array}$ \\
\hline 2 & $\begin{array}{l}\text { Skala Upah } \\
\text { Berubah }\end{array}$ & $\begin{array}{l}\text { Upah disesuikan dengan harga pasar yang didampingi } \\
\text { dengan jumlah hasil tangkapan. }\end{array}$ \\
\hline 3 & Upah Tingkatan & Bagian upah disesuaikan dengan tingkat kesulitan masing- \\
\hline
\end{tabular}


Nurmala Sari, dkk: Kelayakan dan Keadilan dalam Penetapan Upah masing pekerjaan.

\section{Penetapan Upah Berdasarkan Kelayakan dan Keadilan}

Dalam penetapan upah nelayan dapat diukur dengan tingkat kelayakan dan keadilan, dimana kelayakan merupakan aspek yang menentukan apakah suatu usaha yang akan dijalankan akan memberikan manfaat yang lebih besar di banding dengan biaya yang akan dikeluarkan. Sedangkan keadilan merupakan suatu perilaku yang seimbang atau tidak berat sebelah dalam arti tidak memihak pada sesuatu yang nantinya akan menimbulkan kezaliman. Dalam hal ini dapat dijelaskan bahwa kelayakan diukur dari tenaga yang dikeluarkan dapat menghasilkan upah yang banyak serta dapat memenuhi kebutuhan. Sedangkan keadilan berarti upah yang didapatkan sesuai dengan tingkat kesulitan pekerjaan yang dikerjakan.

Dalam penelitian ini yang akan dilihat adalah kelayakan dan keadilan yang didapatkan oleh nelayan kapal pukat langgar di Kuala Langsa mengenai upah yang diterimanya. Adapun paparan hasil penelitian dari Syafrizal sebagai nelayan mengenai kelayakan dan keadilan dalam penetapan upah yang menyatakan bahwa:

"Menurut saya tenaga yang dikeluarkan untuk bekerja sudah sesuai dengan upah yang diberikan. Untuk upah yang saya terima sekitar Rp. 100.000,- / 5 hari sampai Rp. 3.000.000,- / 5 hari kerja dan upah yang saya terima cukup untuk memenuhi kebutuhan. Saya juga mendapatkan imbalan selain upah berupa uang seperti uang sokong dan tunjangan hari raya".

Dari pernyataan tersebut menjelaskan bahwa upah yang diterimanya dapat memenuhi kebutuhan dan besaran upah tersebut sudah sesuai dengan tenaga yang dikeluarkannya dalam bekerja. Sedangkan dalam observasi penelitian, di saat keadaan laut tidak baik yang menyebabkan nelayan tidak pergi melaut, para nelayan memiliki pekerjaan cadangan yaitu mencari ikan dengan menggunakan kapal jaring yang beroperasi di pinggir laut dataran rendah, dimana hasil tangkapan tersebut langsung dijual ataupun di olah menjadi ikan asin dan kemudian di jual guna memenuhi kebutuhan keluarga.

Kelayakan dan keadilan bagi nelayan kapal pukat langgar tidak terprogram dengan sistematis, akan tetapi aspek kelayakan dan keadilan dapat dilihat dari hal- 
hal yang dianggap dapat membantu mensejahterakan nelayan, seperti sebagai berikut:

1. Jaminan Kesehatan

Berdasarkan pernyataan dari Bapak Haji Amir sebagai pemilik kapal, terkait pemberian jaminan kesehatan menyatakan bahwa "jaminan kesehatan ada, jadi bagi nelayan yang mengalami kecelakaan dalam bekerja, kami akan bertanggung jawab untuk memberikan uang buat berobat kedokter."

Hal ini juga sejalan dengan pernyataan dari Rizal sebagai nelayan yang bekerja pada kapal pukat langgar yang menyatakan bahwa "kalau terjadi kecelakaan saat bekerja, biaya berobat itu di tanggung sama toke dan malah dikasih uang tambahan karena sakit." Dari data tersebut dapat dilihat bahwa kapal pukat langgar yang ada di Kuala Langsa memberikan jaminan kesehatan bagi nelayan yang bekerja padanya serta sangat mengedepankan keselamatan para pekerja selama berada di kapal saat melaut.

2. Pemberian Uang Sokong

Dalam pemberian uang sokong menjadi salah satu dukungan semangat para pekerja. Adapun paparan dari Bapak Ridwan sebagai pemilik kapal yang menyatakan bahwa "sebelum kapal berangkat, saya selalu memberikan uang sokong atau uang belanja kepada semua anak buah kapal, jumlah uang yang saya berikan tidak menentu, kadang saya kasih Rp. 50.000,- dan paling sedikit Rp. 30.000,- / orang."

Kemudian hal serupa juga diungkapkan oleh Syafrizal sebagai nelayan yang menyatakan bahwa "saya juga mendapatkan imbalan selain upah yaitu uang sokong. Biasanya uang sokong diberikan pada saat sebelum pergi ke laut dengan jumlah uang yang diberikan paling sedikit Rp. 30.000,- dan itu diberikan secara merata pada setiap nelayanu."

Dari data tersebut dapat disimpulkan bahwa adanya pemberian uang sokong meringankan para pekerja dalam hal belanja keperluan saat hendak pergi melaut.

3. Tunjangan Hari Raya

Dalam pemberian tunjangan hari raya sebagaimana yang diungkapkan Bapak Haji Amir sebagai pemilik kapal menyatakan bahwa "setiap megang puasa dan megang hari raya, baik itu hari raya idul fitri maupun idul adha, 
kami selalu memberikan tunjangan hari raya kepada para nelayan dengan berupa uang".

Kemudian hal yang serupa juga diungkapkan oleh Syafrizal sebagai nelayan yang menyatakan bahwa "setiap tahun kami memang selalu diberi tunjangan hari raya berupa uang yang kami gunakan untuk membeli daging untuk makan keluarga di rumah, biasanya diberikan sebelum megang atau selama megang puasa ataupun hari raya dan jumlahnya sekitar Rp. 150.000,- sampai Rp. 200.000,- paling banyak".

Dari data tersebut dapat disimpulkan adanya pemberian tunjangan hari raya dapat membantu kebutuhan keluarga nelayan saat menjelang puasa ataupun hari raya dan jumlah uang yang diberikan pun dapat mencukupi kebutuhan.

4. Pemberian Ikan Konsumsi

Berdasarkan pernyataan dari Bapak Haji Amir sebagai pemilik kapal menyatakan bahwa "setiap kapal yang sudah pulang dari laut, pawangnya itu sudah menyediakan ikan yang akan diberikan kepada semua anak buah kapal".

Kemudian begitu juga Syafrizal sebagai nelayan menyatakan bahwa "waktu pulang kapal dari laut dan pekerjaan di dalam kapal sudah selesai, kami dikasih jatah ikan makan untuk di bawa pulang".

Berdasarkan data tersebut menjelaskan bahwa memberikan ikan konsumsi kepada para nelayan sudah sangat baik dalam mensejahterakan nelayan. karena upah yang mereka dapatkan bisa untuk keperluan lain yang berarti tidak perlu lagi digunakan untuk membeli ikan sebagai konsumsi keluarga.

Dari paparan hasil penelitian di atas dapat disimpulkan bahwa dalam penetapan upah, pemilik kapal pukat langgar di Kuala Langsa memiliki etika bisnis Islam yang diukur dari program kelayakan dan keadilan yang tersusun tidak sistematis dan tidak terencana. Adapun beberapa program yang terlaksanakan dapat dilihat pada tabel sebagai berikut:

Tabel 1.3.

\section{Program Kelayakan dan Keadilan}

\begin{tabular}{|l|l|}
\hline No. & Program Kelayakan dan Keadilan \\
\hline 1 & Jaminan Kesehatan \\
\hline
\end{tabular}




\begin{tabular}{|l|l|}
\cline { 2 - 2 } 2 & Pemberian Uang Sokong \\
\hline 3 & Tunjangan Hari Raya \\
\hline 4 & Pemberian Ikan Konsumsi \\
\hline
\end{tabular}

\section{Temuan Penelitian Dalam Perspektif Etika Bisnis Islam}

Secara sederhana etika bisnis Islam mempelajari tentang moralitas, dimana pelaku bisnis dapat membedakan mana yang baik dan buruk atau benar dan salah dalam dunia bisnis. Dikarenakan usaha kapal pukat langgar merupakan usaha perseorangan yang berarti hanya memiliki satu pemilik usaha maka penerapan etika bisnis Islam ditujukan kepada pemilik kapal. Namun kapal pukat langgar yang ada di Kuala Langsa ini tidak di kelola langsung oleh pemilik kapal, melainkan di kelola oleh pengelola yang disebut pawang, sehingga etika bisnis Islam juga berlaku jika ditujukan kepada pengelolanya.

Dalam proses penetapan pembayaran upah nelayan kapal pukat langgar di Kuala Langsa terjadi menjadi dua kebijakan, pertama kebijakan kesepakatan bersama antara pemilik kapal dengan pengelola, kedua kebijakan yang ditetapkan secara sepihak yang berarti kebijakan penetapan upah para nelayan di atur oleh pengelola tanpa campur tangan pemilik kapal. Dalam hal ini, penulis berasumsi bahwa kapal pukat langgar yang menerapkan kebijakan secara sepihak akan menimbulkan perselisihan dan penetapan upah yang tidak sistematis. Sehingga lebih baiknya apabila penetapan upah tersebut dilakukan sesuai kesepakatan bersama agar terjadi transparansi dalam penetapan upah nelayan tersebut. Dari lima kapal pukat langgar yang di teliti penulis, ada dua kapal yang menerapkan kebijakan penetapan upah secara sepihak, dalam hal ini kecil kemungkinan terjadinya perselisihan karena lebih banyak pemilik kapal yang peduli dengan nelayan-nelayannya sehingga penetapan upah tersebut dilakukan secara bersama.

Dalam peneriman upah nelayan sudah dikategorikan cukup baik karena upah tersebut cukup untuk kebutuhan sehari-hari, dalam bekerja pun mereka diberikan sarana yang menjadi alat pendukung dalam bekerja. Selain itu, para nelayan juga mendapatkan imbalan selain upah yaitu uang sokong, ikan konsumsi, tunjangan hari raya dan jaminan kesehatan dari pemilik kapal apabila terjadi kecelakaan saat bekerja, sehingga meringankan biaya keluarga nelayan tersebut. 
Dari imbalan yang diberikan menunjukkan bahwa pemilik kapal dan pengelola kapal pukat langgar di Kuala Langsa sudah memenuhi prinsip kelayakan.

Sementara, dalam proses bekerja pada kapal pukat langgar tidak ada perjanjian secara tertulis mengenai penetapan upah, namun ada perjanjian dalam penempatan tingkatan pekerjaan dan juga tingkat bagian upah yang didapatkan dimana perjanjian tersebut juga secara lisan. Walaupun tingkat bagian upahnya berbeda tetapi jumlah upah pokok yang diberikan sama rata. Hal ini menunjukkan adanya prinsip keadilan yang cukup baik karena besaran bagian upah yang didapatkan oleh nelayan sesuai dengan tingkatan pekerjaan yang dilakukan.

Secara garis besar, proses penetapan pembayaran upah pada kapal pukat langgar di Kuala Langsa tidak bertentangan dengan konteks etika bisnis Islam, namun dapat dikatakan cukup baik karena masih ada kekurangan yaitu ketiadaan perjanjian kerja secara tertulis yang dapat menyebabkan pemutusan pekerja secara sepihak. Akan tetapi dari sisi kelebihannya yaitu hak dan kewajiban dari masingmasing pihak sudah terlaksanakan dan dalam penetapan upah juga terjadi kerelaan dari masing-masing pihak serta penghasilan ikan yang didapatkan juga dihitung secara transparansi sehingga kecil kemungkinan terjadi kecurangan. Selain itu, prinsip kelayakan dan keadilan juga sudah berjalan cukup baik dalam penetapan upah nelayan tersebut.

\section{Jenis-jenis Upah Yang Dipraktikkan Pada Kapal Pukat Langgar Berdasarkan Etika Bisnis Islam}

Dalam kegiatan usaha kapal pukat langgar di Kuala Langsa jika ditinjau berdasarkan etika bisnis Islam, maka penetapan upah yang dipraktikkan termasuk dalam Ujrah Samsarah karena upah tersebut ditetapkan dengan pertimbangan harga objek transaksi atau pelayanan. Upah yang diberikan pemilik kapal kepada nelayan juga termasuk upah yang sepadan dengan kerjanya serta sepadan dengan kondisi pekerjaannya (Ujrah al-misli), karena upah yang diberikan oleh pemilik kapal sesuai dengan tingkat kesulitan pekerjaan yang ditanggung oleh nelayan sehingga upah yang didapatkan sepadan dan disertai dengan adanya kerelaan dari masing-masing pihak yang melakukan transaksi terhadap upah tersebut.

Islam memberikan kebebasan kepada pemeluknya untuk bekerja, namun dalam Islam ada beberapa prinsip dasar yang menjadi etika normatif yang harus 
ditaati ketika seorang muslim akan dan sedang bekerja, antara lain: Pertama, Ash Sholah (baik dan bermafaat). Pekerjaan yang dituntut untuk dilakukan atas diri seseorang haruslah yang baik dan bermafaat (al-Amal As-Shalih). Kedua, Al-Itqan berarti kesungguhan dan kemantapan dalam melaksanakan suatu tugas, sehingga dikerjakannya secara maksimal, tidak asal-asalan, sampai dengan pekerjaan tersebut tuntas dan selesai dengan baik (Fakhry Zamzam dan Havis Aravik, 2020). Etika bisnis Islam juga mengedepankan prinsip kesatuan (tauhid), keseimbangan (adil), kehendak bebas (ikhtiyar) dan tanggung jawab (Djakfar, 2007). Maka pelaku bisnis yang beriman harus menerapkan prinsip tersebut dalam menjalankan suatu pekerjaan semata-mata untuk ibadah, taat, bekerja keras serta mengembangkan nilai-nilai kebaikan. Islam memberikan pekerjaan dunia ini dan menjadikannya bagian dari pada ibadah dan jihad apabila pekerjaan tersebut dilakukan secara konsisten terhadap peraturan Allah SWT, niat karena-Nya dan tidak melupakan-Nya.

Mengenai penyerahan upah ini secara terperinci dalam Islam telah memberikan pedoman yaitu memberikan upah yang adil dan layak, menganjurkan untuk membayar upah setelah pekerjaan yang dilakukan selesai dan mempercepat pembayaran upah pekerja.

Penetapan upah nelayan pada kapal pukat langgar di Kuala Langsa sudah sesuai dengan Etika Bisnis Islam, karena berdasarkan prinsip keadilan pembagian upah dalam masyarakat Islam yang telah ditetapkan melalui negosiasi antara pemilik kapal dan nelayan. Dalam Islam juga dijelaskan bahwa antara pengusaha dan pekerja di larang berbuat dzalim dan aniaya, maka keadilan diantara mereka harus ditegakkan. Dalam hal ini, para nelayan tidak ada yang merasa teraniaya karena pembagian upah disesuaikan dengan tingkat pekerjaan yang mereka kerjakan serta pembayaran upah juga dilakukan secepatnya setelah hasil tangkapan ikan terjual dan masing-masing nelayan juga mendapatkan besaran upah sesuai dengan bagian-bagiannya tanpa ada yang bersikap dzalim terhadap yang lainnya. Menurut penulis, kelemahan dari masing-masing pihak ada pada perjanjian kerja yang dilaksanakan secara lisan, namun yang menjadi dasar analisa penulis bahwa penetapan upah nelayan kapal pukat langgar di Kuala Langsa sudah sesuai berdasarkan etika bisnis Islam adalah sudah terpenuhinya hak dan kewajiban dari masing-masing pihak, baik pemilik kapal maupun para nelayan. 
Nurmala Sari, dkk: Kelayakan dan Keadilan dalam Penetapan Upah

Konsep kelayakan dan keadilan menjadi hal mutlak dari masing-masing pihak yang sudah terpenuhi, tidak ada yang merasa dirugikan. Kedua belah pihak merasa saling mendapatkan manfaat dari usaha tersebut.

\section{SIMPULAN}

Hasil penelitian ini dapat disimpulkan sebagai berikut:

1. Penetapan upah nelayan kapal pukat langgar di Kuala Langsa menggunakan sistem upah sebagai berikut:

a. Upah bagi hasil yaitu pendapatan sesuai persentase bagi hasil antara pemilik kapal dengan pekerja (nelayan).

b. Skala upah berubah yaitu upah disesuaikan dengan harga pasar yang didampingi dengan jumlah hasil tangkapan.

c. Upah tingkatan yaitu bagian upah disesuaikan dengan tingkat kesulitan masing-masing pekerjaan. Dimana penerapan prinsip kelayakan dan keadilan dalam penetapan upah tersebut dibuktikan dengan adanya pemberian jaminan kesehatan, pemberian uang sokong, tunjangan hari raya dan pemberian ikan konsumsi.

2. Pandangan Etika Bisnis Islam tentang kelayakan dan keadilan dalam penetapan upah nelayan kapal pukat langgar di Kuala Langsa sudah cukup baik. Dalam hal ini, para nelayan tidak ada yang merasa teraniaya karena pembagian upah disesuikan dengan tingkat pekerjaan yang mereka kerjakan serta pembayaran upah juga dilakukan secepatnya setelah hasil tangkapan ikan terjual dan masing-masing nelayan juga mendapatkan besaran upah sesuai dengan bagianbagiannya tanpa ada yang bersikap dzalim terhadap yang lainnya.

\section{PUSTAKA ACUAN}

Chaudhry Muhammad Sharif.(2012). Sistem Ekonomi Islam: Prinsip Dasar, Jakarta: Kencana, cet 1 .

Djakfar Muhammad. (2007). Etika Bisnis dalam Perspektif Islam, Malang: UIN Malang Press, cet 1.

(2012). Etika Bisnis: Menangkap Spirit Ajaran Langit dan Pesan Moral Ajaran Bumi, Jakarta: Penebar Plus.

Kasmir. (2013). Studi Kelayakan Bisnis, Jakarta: Kencana, cet 9. 
Rivai Veithzal, et al.(2012). Islamic Business and Economic Ethics, Jakarta: Bumi Aksara.

Sugiyono.(2010). Metode Penelitian Pendidikan (Pendekatan Kuantitatif, Kualitatif, dan $R \& D$ ), Bandung: Alfabeta, 2010.

Sukirno Sadono. (2013). Mikro Ekonomi: Teori Pengantar, Jakarta: Raja Grafindo Persada.

Syamsuri.(2007). Pendidikan Agama Islam, Jakarta: Erlangga.

Wati Lina Asmara. (2018). Ekonomi Produksi Perikanan dan Kelautan Modern, Malang: UB Press.

Zamzam Fakhry dan Aravik Havis.(2020). Etika Bisnis Islam: Seni Berbisnis Keberkahan, Yogyakarta: CV BUDI UTAMA, cet 1.

Fitri Amalia. (2014) “Etika Bisnis Islam: Konsep dan Implementasi Pada Pelaku Usaha Kecil”, dalam Jurnal Al-Iqtishad, Vol. IV, No. 1. 